\title{
INFORMATION AND COMMUNICATION TECHNOLOGY APPLICATIONS IN THE TANZANIAN HEALTH SECTOR
}

\author{
Matern A.M. Victor and Edna S. M. Ndumbaro(Mrs) \\ Department of Engineering Management and Entrepreneurship, \\ University of Dar es Salaam \\ P. O. Box 35131, DAR ES SALAAM \\ mmvictor@uccmail.co.tz
}

\begin{abstract}
7 he potential role of Information and Communication Technology (ICT) in the health sector is to improve the delivery of health services and would also help to deal with major constraints in uplifting the health standards of Tanzanians. ICT in heath can be used to facilitate remote consultation, diagnosis and treatment. The objective of the study was exploratory in nature and aimed at determining the awareness level of the Tanzanian health sector on various ICT applications which could be used in the sector. The study also aimed at establishing the challenges to the implementation of ICT in the Tanzanian health sector. A survey approach with the use of a questionnaire applied to a sample of health care providers in Tanzania was used as a research methodology. The significance of this research is to raise awareness of the impact of ICT in health sector in Tanzania, and adoption of basic applications in ICT after collaboration with other stakeholders. The main problems identified in the findings were lack of ICT-skills and education, inadequate infrastructure, finance and ICT support structure. The main conclusion is that the development of ICT in the health sector of Tanzania needs an integrated effort across sectors and among the stakeholders.
\end{abstract}

Keywords: ICT, Health sector, Tele-consultation, E-mail, Computer networks.

\section{INTRODUCTION}

The ICT sector is a range of industries and services activities - Internet service provision, telecommunications equipment and services, information technology equipment and services, media and broadcasting, libraries and documentation centers, commercial information providers, network-based information services and other related information and communication activities [ECA, 1999]. By adopting ICT in the health sector many benefits can be realized ranging from improved management and administration of health institutions, fostering teaching and research, supporting decision making on curative and preventive health, improving distribution of medical supplies and bridging the gaps between access to health services in rural and urban areas [Adam, 2000]. Most of the populations of
Tanzania live in rural and often isolated areas. This is also where most of the natural resources are located. Access to information and telecommunications is still predominantly in urban areas particularly Dar es Salaam [Nnafie, 2002].

Healthcare in Tanzania is one of the largest industries in terms of the number of customers it attracts everyday, but it is very complex, cumbersome and paper-based. Tanzania is facing a continuous health threat characterized by spread of infectious diseases, ravaging epidemics, declining life expectancy, high levels of infant mortality and deteriorating healthcare facilities. As a result, as we begin a new century the promise of good health for the people seems far from reality. The HIV/AIDS, tuberculosis, cholera and Malaria diseases are likely to diminish life expectancy, decrease work 
productivity and increase infant mortality. This paper reports on a research work done in Tanzania aimed at establishing the extent of ICT usage in the country's health sector. The paper starts with a short relevant literature followed by the findings. The findings cover items such as the composition of the respondents, skills and training, issues of hardware and software, network and Internet access. The paper finally gives conclusions and recommendations.

\section{LITERATURE REVIEW}

When strategically deployed, ICT can trigger a development dynamic, one that gains momentum as targeted steps are taken in such key areas as policy, infrastructure, human capacity, entrepreneurship, and development of locally relevant content and applications. A strategic framework can be used by countries to create a cycle of sustainable development and achieve a range of social goals such as healthcare, education and increased economic activity. However, it is stressed that such strategies will be effective only if they involve the full range of stakeholders in international development governments, both industrialized and developing, the business and non-profit sectors, multilateral agencies, and community organizations on the ground, [UNDP et al, 2001]. According to the African Information Society Initiative (AISI) framework, development of National Information and Communications Infrastructure (NICI) plans requires developing and improving the following four major components [ECA, 1999]:

\section{Institutional framework and legal, regulatory and management mechanisms}

Human resources:- Development of human resources also requires having a new profile of management/labour forces; the ability to adapt, adopt and exploit new technologies and to manage the change; and creating new job markets where skills and knowledge learned can be applied. Capacity building programs should be developed and tailored to the need of each user.
Information resources:- Information structure development where the major issue is, on the one hand, to ensure affordable and easy access to global information and, on the other hand, to assure the generation, utilization and commercialization, where applicable, of local information and knowledge resources.

Technological resources (Infrastructure):Effective information and communication systems require reliable, low-cost and widespread technological resources such as computers, software and all the components of the telecommunications infrastructure for processing data and information. It will be necessary to upgrade and develop the physical and logical telecommunication infrastructure and network at the national level, in addition to improving continental interconnectivity and providing gateways to international telecommunication networks.

According to UNECA [2001], in Africa there is fragmentation in information technology use in the health sector, which has led to islands of automation with few links among them, calling for more unified approach at national levels. Governments need to define standards and provide the technological infrastructure and services required for the use of ICT in health. They also need to set up incentives to encourage ICT health applications (e.g. reduction of tax rates on equipment and of telecommunication service tariffs, introduction of rates for rural areas that are lower than those for urban areas, etc.). UNECA [2001] also identified major challenges in information access as being:

- Improving access to telecommunications and computing infrastructure;

- Increasing the availability of applications; Expanding computer literacy; Improving consumer demand for health information; Surmounting resistance;

- Developing strategies for bridging the financial resources gap especially in the initial implementation and maintenance costs. 
The chronic shortage of doctors and mid-level practitioners in rural areas will not decrease in the near future. ICT applications such as telemedicine present a considerable opportunity to narrow the expertise gap in rural areas. Telemedicine makes remote areas more accessible by giving them immediate electronic access to up-to-date information and resources and specialists for consultative purposes. By reducing the need for referrals, it helps patients remain in their communities, provides faster, more convenient treatment and minimizes the disruption of the patient's life. However, the communication infrastructure is unable to support the bandwidth necessary to carry the signals for telemedicine using two-way interactive video [UNECA, 2001]. ICT tend to alter the organizational settings of health workers that are generally rigid and hierarchical. This research tries to address the need for the health sector to become flexible and innovative through the use of ICT. It consists of survey results obtained from various purposely selected institutions in the health sector in Tanzania

\section{METHODOLOGY}

The study methodology adopted for this study was descriptive study design. Descriptive studies are designed to gain more information about characteristics within a particular field of study than any other research approach (Burns and Grove, 1993). The descriptive study design is used to examine characteristics of a single sample. The design enables the identification of the phenomenon of interest, and the variables within the phenomenon. A descriptive design may be used for the purpose of developing theory, identifying problems with current practice, justifying current practice, making judgments, or determining what others in similar situations are doing.

A questionnaire designed to assess awareness, level of current use and attitude was sent to organizations with leading health services in Tanzania. The survey addressed key topics influencing the ICT health sector including hardware, software, knowledge base, ICT strategies and access to Internet based services. All topics focused on computers and their use for delivering quality health information systems

\section{RESULTS AND DISCUSSION}

A total of 26 responses were received out of 34 , questionnaires sent, giving a response rate of over $75 \%$. Of the received responses private hospitals constituted about $65 \%$ of the respondents, with the rest being either government medical research institutions or hospitals. Hospitals with leading services chosen in the survey were mostly found in the competitive private sector. Regarding the size of the institutions, about $70 \%$ of total respondents had above 100 employees and $65.2 \%$ of hospitals had 50 beds or more. The organization structures of over three quarters of the surveyed health centers do not have ICT clusters. This is a setback in the recent finalized national ICT policy, as one of the focus areas in harnessing ICT in Tanzania is strategic leadership. Having IT clusters shows commitment in the management level. Table 1 summarizes the positions of respondents. It can be seen that the respondents were distributed in the various positions.

Table 1: Characteristics of respondents

\begin{tabular}{llcc}
\hline Positions of Respondents & & Response in $\%$ \\
\hline System administrators, IT managers or directors of IT & & 23.08 \\
\hline CEOs, executive directors, managing directors or hospital & 19.23 \\
directors. & & & 26.92 \\
\hline $\begin{array}{l}\text { Physicians, medical physicists, surgeon-in-chief, } \\
\text { hospital director, regional nursing officers, } \\
\text { scientist or dentists. }\end{array}$ & & & \\
\hline $\begin{array}{l}\text { Financial controllers, administrators, reform manager, hospital } \\
\text { secretary or personal secretaries }\end{array}$ & & Total & 100 \\
\hline
\end{tabular}




\section{Skills and Training}

For organizations with IT clusters usually there are programs for human capacity development that will result into knowledgeable workers and increase in technical skills among users. Those with IT clusters had better response in the skills and training of its employees. Over two thirds of the surveyed sample had only up to a quarter of its employees trained in computer basic skills. The results are as summarized in table 2 over three quarters of respondents say only up to a quarter of health professionals use computers institutions own ultrasound, mammography, $\mathrm{X}$ ray and fluoroscopy equipment, only few own equipment such as computerized topology (CT) scanner and EEG analyzer. None of the surveyed institutions own magnetic resonance imaging (MRI) equipment. The main reason advanced for this kind of distribution is the high cost of acquiring some of these equipments, as they are expensive and have to be imported.

\section{Software and Networking}

Over two thirds of respondents $(70.8 \%)$ use other application software to solve specific Table 2: Employees with computer basic skills and those using computers problems other than

\begin{tabular}{lccc}
\hline Ratio & $\begin{array}{l}\% \\
\text { employees } \\
\text { computer } \\
\text { skills }\end{array}$ & $\begin{array}{r}\text { of } \\
\text { in }\end{array}$ & $\begin{array}{l}\% \text { of } \\
\text { professionals using } \\
\text { computers }\end{array}$ \\
\hline $\begin{array}{l}\text { Up to } \\
\text { quarter }\end{array}$ & 68 & 7.69 \\
\hline Up to a half & 20 & 19.23 \\
\hline $\begin{array}{l}\text { Up to three } \\
\text { quarters }\end{array}$ & 4 & 15.38 \\
\hline $\begin{array}{l}\text { More than } \\
\text { three quarters }\end{array}$ & 8 & - \\
\hline & 100 & 100 \\
\hline
\end{tabular}

\section{Hardware}

Computers are the main ICT equipment and therefore this study sought to find out their presence in the various visited institutions. As shown in Table 3 all surveyed institutions had at least one computer with about $70 \%$ of them having 5 or more computers as for the other computerized medical equipment, Table 4 shows in percentage the institutions that own the more common type of equipment. It is seen here that while over two thirds of the surveyed word processing and over a quarter $(29.2 \%)$ uses them for word processing only. Majority of respondents have patient administration system $(82.4 \%)$ and less than a quarter have systems for demographic movement of patient
Table 4: Computerized medical equipment owned by surveyed institutions

\begin{tabular}{|c|c|c|c|}
\hline Equipment & $\begin{array}{l}\text { Response } \\
\text { in } \%\end{array}$ & Equipment & $\begin{array}{l}\text { Response } \\
\text { in \% }\end{array}$ \\
\hline $\begin{array}{l}\text { EEG } \\
\text { analyzer }\end{array}$ & 11.76 & $\begin{array}{l}\text { Ultrasound and } \\
\text { mammography }\end{array}$ & 88.24 \\
\hline $\begin{array}{l}\text { ECG } \\
\text { analyzer }\end{array}$ & 58.82 & $\mathrm{X}$-ray and fluoroscopy & 76.47 \\
\hline $\begin{array}{l}\text { Cardiac } \\
\text { echo }\end{array}$ & 47.02 & MRI equipment & 0 \\
\hline $\begin{array}{l}\text { CT } \\
\text { Scanner }\end{array}$ & 23.5 & $\begin{array}{l}\text { Others -Gamna camera, } \\
\text { cardiac assisting } \\
\text { devices, telemetry } \\
\text { monitoring, stress ECG, } \\
\text { cell dyne pathology }\end{array}$ & 29.41 \\
\hline
\end{tabular}

Table 3: Possession of computers

\begin{tabular}{lc}
\hline $\begin{array}{l}\text { No. of } \\
\text { computers }\end{array}$ & Response in \% \\
\hline None & - \\
\hline Less than 5 & 30.77 \\
\hline More than 5 & 69.23 \\
\hline Total & 100 \\
\hline
\end{tabular}

$(17.7 \%)$. Figure 1 summarizes the available digital information systems. Other specialized systems as shown in Figure 1 as being owned by about half of the respondents are either for billing, image transfer, research data manipulation and analysis and demographic surveillance of population. 
More than half of the surveyed institutions have not networked their computers for communication purposes. Table 5 summarizes extent of various networking modes.

Various reasons were given for not networking computers either between or within sites. A

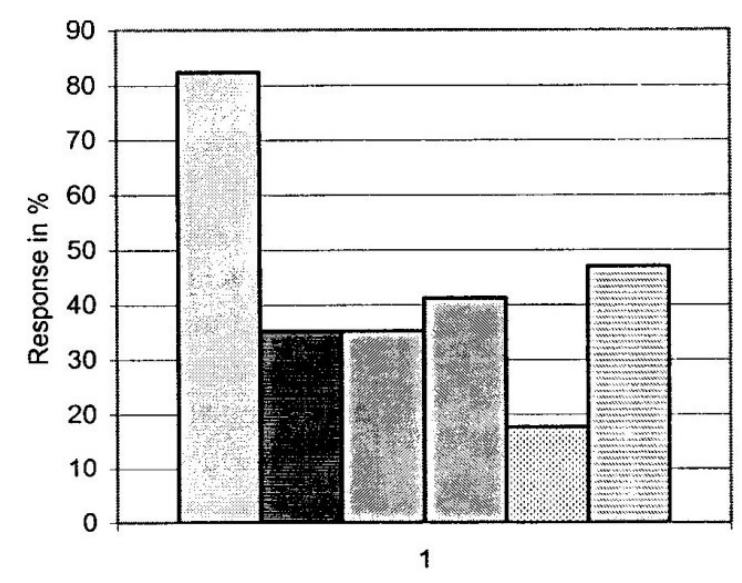

Figure 1: Digital Information Systems

Table 5: Networking Status

\begin{tabular}{lc}
\hline Networking mode & $\begin{array}{c}\% \text { of } \\
\text { Institutions }\end{array}$ \\
\hline Not networked & 53.85 \\
\hline Networked within sites & 34.62 \\
\hline $\begin{array}{l}\text { Networked both within and } \\
\text { between }\end{array}$ & 7.7 \\
\hline Networked between sites & 3.85 \\
\hline
\end{tabular}

quarter of the responses don't understand the technology and more than half are in the process of networking. Figure 2 summarizes the reasons for not networking.

A majority $(92.3 \%)$ of the respondents said that their computer systems can't be remotely accessed. Only few use it occasionally or frequently $(3.9 \%)$. Key telemedicine applications such as patient home clinical

\begin{tabular}{|l|}
\hline Patient Administration \\
System \\
Clinical Laboratory \\
Services \\
Workstations for \\
Emergency \\
Department \\
$\square$ Drug use \\
$\square$ Demographic \\
movement of patient \\
$\square$ Other
\end{tabular}

analyzers are not used. Very few (4.3\%) use mobile monitoring clinical analyzers. In the mobile case, measured signals will be transferred via Global System for Mobile (GSM) network to the specialist or hospital ambulances. Home hospitals and home care services are the primary users of mobile analyzers. In the patient home clinical analyzers case, self-measured results can be sent via Internet or GSM links to the patient's family doctor. These applications are targeted to patients having asthma, diabetes or high blood pressure.

\section{Access to Internet based services}

Over a third $(34.6 \%)$, of the surveyed institutions has a website for promotion of their activities. The website interaction capabilities are not used to solicit feedback from visitors of the site, such as patients, medical suppliers, etc. A majority of respondents $(88.5 \%)$ have Internet/Email services and less than a quarter are strongly considering having Internet/Email services in the near future. Majority $(87 \%)$ of respondents frequently use external mail while of those with local area network $(46.1 \%)$, over two thirds $(68.3 \%)$ frequently use internal mail. Table 6 summarizes extent of E-mail use

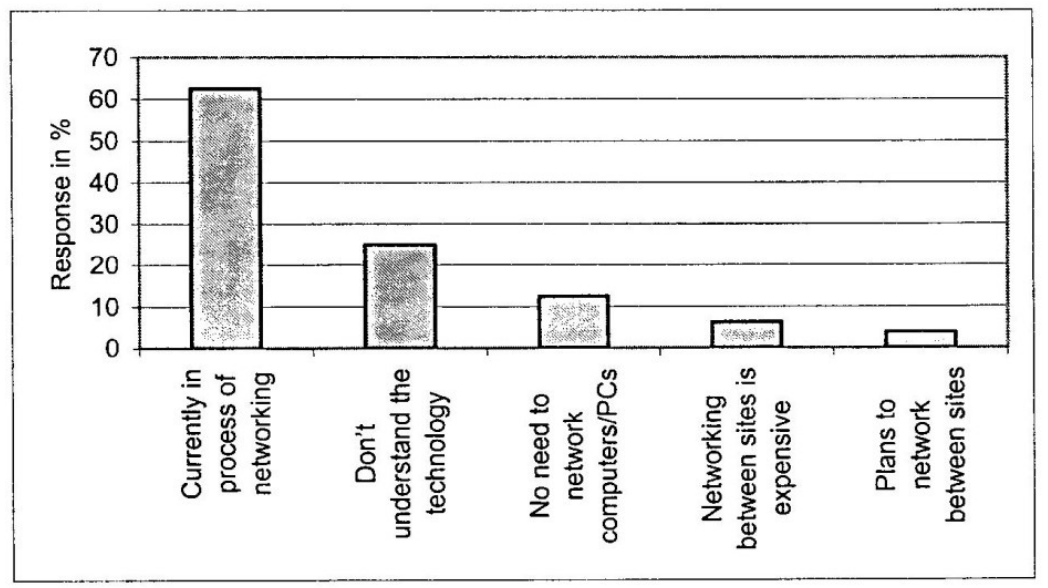

Figure 2: Reasons of not networking 
More than two thirds $(69.6 \%)$ of the responses accessed the Internet for reasons other than for email use hence consultation of relevant information by trained health professionals is

Table 6: Extent of E-Mail Use

\begin{tabular}{lcc}
\hline Nature of use & \multicolumn{2}{c}{$\begin{array}{c}\text { Percentage of } \\
\text { respondents }\end{array}$} \\
\cline { 2 - 3 } & $\begin{array}{c}\text { Internal } \\
\text { Mail }\end{array}$ & External Mail \\
\hline Frequently & 68.3 & 87.1 \\
\hline Occasionally & 1.7 & 9.9 \\
\hline Rarely & 9.0 & 0 \\
\hline Not used & 21.0 & 3.0 \\
\hline
\end{tabular}

possible. Over half $(56.52 \%)$ of the responses are directly linked from the computer via modem and telephone line. Use of Wireless Local Loop (WLL) instead of cables is not very popular as the mostly used links are cables that are costlier to the user in terms of phone bills and maintenance. There are clear differences between conducted and radiated systems. Wired technology requires that cables be run from all points of communication to all other points of communication. This can be very costly if the target locations are far spread from one another. The lines need to be maintained if damaged. A big advantage of radiated systems is the lack of wires. Therefore, they offer great ease of configuration and reconfiguration. In fact, they are highly portable. Cellular, paging and various wireless systems also offer the advantage of mobility, and wired systems just do not. Table 7 summarizes the types of links to the Internet.

Three quarters of the surveyed institutions noted that computers are dedicated for specialized

Table 7: Types of links to the Internet

\begin{tabular}{lc}
\hline \multicolumn{1}{c}{ Link } & \%connected \\
\hline $\begin{array}{l}\text { Direct from the computer/PC via } \\
\text { modem and telephone line }\end{array}$ & 56.52 \\
\hline $\begin{array}{l}\text { Direct from the computer/PC via } \\
\text { modem and ISDN line. }\end{array}$ & 4.35 \\
\hline $\begin{array}{l}\text { Direct from the computer/PC via } \\
\text { cable modem and network }\end{array}$ & 13.04 \\
\hline Via the LAN & 39.13 \\
\hline Other -wireless & 4.35 \\
\hline
\end{tabular}

duties. As an example, e-mail has great advantage over fax due to the higher cost of dedicating a phone line to a fax machine and the higher cost of calls. More than two thirds of the respondents do not practice tele-consultation. Tele-consultation is used between hospitals and health care centers, consultative and interactive referral between general practitioner (GP) and the specialist. Some respondents, who were eager to practice teleconsultation, noted that the infrastructure is not in place to facilitate transfer of digital images due to absence of higher bandwidth.

\section{Access to knowledge base}

Majority ( $88 \%$ ) of the responses say they use $\mathrm{CDs}$ or CD-ROMs. Over three quarters (77.3\%) of the respondents 'either use CDs for support material or storing data and slightly less than half $(45.5 \%)$ use them for training. As an example of use in training, in public health information on health topics such as HIV/AIDS, they allow two way flow of information in frequently asked questions and answers.

The majority of health professionals do not utilize centralized data stores on issues such as scheduling of patients and re-constructive surgery techniques. A few areas that are consulted are on submission of data for research $(38.5 \%)$ and patient treatments $(30.8 \%)$. Issues such as information on essential drugs and public health information are also somehow consulted. Consulting such databases could enable health practitioners to update their medical knowledge. Table 8 summarizes extent of consultation of health networks.

\section{Expected ICT Benefits}

Concerning benefits of ICT, with the exception of promotion of information exchange more than one third are not definite of other benefits. A majority (80.8\%) of responses are aware that ICT can promote information exchange among researchers and students. Over a quarter of respondents doubt on benefits of reducing the costs involved in transporting patients to urban facilities, 
promotion of healthy behaviors in critical areas such as AIDS and transferring diagnostic information to specialized centers. Nearly two thirds $(65.4 \%)$ are aware that ICT can enhance administration, improve health, improve distribution and reduce cost of medical supplies. Table 9 summarizes the awareness of benefits of ICT in the health sector.

\section{Summary}

Very few health professionals have received formal training on e-based skills i.e. skills to use Internet, including information retrieval and email, and actual usage of computers is low. Networking of computers so as to share the scarce available peripherals, programs or data has not been extensively utilized. With training as one of the leading challenges, ICT innovations such as digital information systems and development of customized software are not popular. There is access to the Internet other than for e-mail use but consultation of relevant information by trained health professionals is under utilized.

Challenges are clearly seen. Financial and technological incapability have affected the use of computerized equipment, specifically for sophisticated and expensive ones. All respondents had both computers and some form of ICT devices in use but some possessed none of the computerized medical equipment as they use traditional analogue or manual operated equipment. Basic applications of teleconsultation are not possible as the basic infrastructure with required bandwidth is not in place even in the urban areas. This is frustrating to some of the leading health centers. There is low awareness of the national ICT policy $(20 \%)$ and few institutions (46\%) have ICT master plans. The above mention setbacks will undermine full exploitation of the potentials of ICT in the health sector.

Table 8: Consultation of health networks (Response in \%)

\begin{tabular}{|c|c|c|c|c|c|}
\hline Issue & $\begin{array}{l}\text { Defini } \\
\text { tely }\end{array}$ & $\begin{array}{c}\text { Somewhat not } \\
\text { sure }\end{array}$ & $\begin{array}{c}\text { Probably } \\
\text { not }\end{array}$ & Never & $\begin{array}{c}\text { No } \\
\text { response }\end{array}$ \\
\hline Patient treatments & 30.8 & 15.4 & 3.9 & 30.8 & 19.2 \\
\hline \multicolumn{6}{|c|}{$\begin{array}{l}\text { Re-constructive surgery } \\
\text { techniques }\end{array}$} \\
\hline \multicolumn{6}{|c|}{ Scheduling of patients } \\
\hline & 3.9 & 3.9 & 19.2 & 50 & 23.1 \\
\hline \multicolumn{6}{|l|}{ Report Progress on } \\
\hline treating diseases & 15.4 & 11.5 & 15.4 & 34.6 & 23.1 \\
\hline \multicolumn{6}{|c|}{$\begin{array}{l}\text { Submission of data for } \\
\text { research }\end{array}$} \\
\hline Essential Drugs & 26.9 & 11.5 & 7.7 & 34.6 & 19.2 \\
\hline Pediatrics & 15.4 & 7.7 & 11.5 & 42.3 & 23.1 \\
\hline \multicolumn{6}{|c|}{ Public health promotion } \\
\hline & 26.9 & 3.9 & 11.5 & 38.5 & 19.2 \\
\hline
\end{tabular}


Table 9: ICT benefits (Response in \%)

\begin{tabular}{lccccc}
\hline \multicolumn{1}{c}{ Benefits } & Definitely & Not sure & Not Probably & Never & No response \\
\hline $\begin{array}{l}\text { Can reduce the costs } \\
\text { involved in transporting } \\
\text { patients to urban facilities. }\end{array}$ & 53.9 & 19.2 & 0 & 15.4 & 11.5 \\
\hline $\begin{array}{l}\text { Promote healthy behaviors } \\
\text { in critical areas such as }\end{array}$ & 65.4 & 19.2 & 0 & 11.5 & 3.9 \\
AIDS. & & & & & \\
\hline $\begin{array}{l}\text { Promote information } \\
\text { exchange among } \\
\text { researchers and students. }\end{array}$ & 80.8 & 3.9 & 7.7 & 0 & 7.7 \\
\hline $\begin{array}{l}\text { Health administration } \\
\text { enhancement, health } \\
\text { improvement, distribution } \\
\text { and reduced cost of } \\
\text { medical supplies. }\end{array}$ & 65.4 & 19.2 & 3.9 & 0 & 11.5 \\
$\begin{array}{l}\text { Transfer diagnostic } \\
\text { information to specialized } \\
\text { centers. }\end{array}$ & & & & & \\
\hline
\end{tabular}

\section{CONCLUSION AND RECOMMENDATIONS}

The potential of ICT use in the health sector may be realized only if those working in the sector are aware of the capabilities of ICT, and those working in ICT research and development become aware of the problems and challenges in the health sector that could be solved using the technology. For active participation in the global information society, tremendous efforts are required to build the capacity.

Regarding the status of ICT applications in healthcare delivery in Tanzania, basic applications such as electronic medical records, hospital information systems, local networks for sharing and distributing information among health workers, provision of remote diagnostics via telemedicine and community health information systems for rural areas are not yet fully developed. The survey results have shown that integration of ICT in the health sector is at its infant stage, as obstacles such as limited infrastructure both in the urban centers, but critically in the rural areas, scarcity of expertise and skills in ICT, insufficient financing, user dissatisfaction with low bandwidth and delayed response, the failure and high cost of the ISP, and poor organizational design are numerous. There is also some resistance among health workers to adopt the new technology.

Tanzania has seen rapid growth in electronic communications usage and this has created both opportunities and challenges. Current evidence in innovative use of ICT by various sectors in Tanzania shows that with the right enabling environment, the health sector can also take full advantage of the ICT revolution. A focus should be made in the development of infrastructure strategies and creation of enabling policy and regulatory environment to ensure developments of ICT in the health sector, improving access to ICT and to build sufficient human resources with high-level skills and entrepreneurship orientation.

There is proof of the commitment of the organizers and funding bodies to support ICT infrastructure. Health policy makers should take cognizance of these initiatives and view them as an excellent resource to improve health information flow to various categories of end users from frontline health workers to community organizations and individuals 
seeking health information. Due to vast information in the health sector there is a need for provision of quality health information to the health workers in their professional activities. This can be achieved by providing a wide range of services including Internet applications such as access to emails and websites. There is a big market for computer training in the health sector. Skills to use Internet, including information retrieval and e-mail are among the needed ones. Refresher or skills upgrading courses are also required, as in most health centers there are no continuous training programs thus skills obtained informally remain at the same level for years. The increase in computing power and connectivity combined with studies that prove the benefits of using electronic medical records leave hospitals with no excuse to adopt computerized record keeping provided other resources are available.

\section{REFERENCES}

1. Adam, L., African health care goes Internet http://www.afrol.com/Categories/Health/heal th038_telehealth.htm Kabissa-Fahamu Newsletter, 2000.
2. Burns, N. and Grove, S.K., The practice of nursing research: Conduct, critique \& utilization, 2nd edition, Philadelphia: Sanders, 1993.

3. ECA, Developing National Information and Communications Infrastructure (NICI) Policies, Plans and Strategies: The 'why' and 'how, The African Development Forum, http://www.un.org/Depts/eca/adf/codipap2.ht m, 1999.

4. Nnafie, I., Internet Cafes in Dar es Salaam: Problems and Opportunities, MSc. Thesis, Eindhoven University of Technology, November, 2002.

5. UNECA, Improved Information and Communication Technologies for the Health Sector in Africa, http://www.un.org/depts/eca/adf/pforum.htm, 2001.

6. UNDP, Accenture, and the Markle Foundation, Information technologies can create social and economic progress in developing countries, The Digital Opportunity Initiative, 2001. 